\title{
MINERAL RESOURCE POTENTIAL OF THE BURDEN FALLS ROADLESS AREA, POPE COUNTY, ILLINOIS
}

By

John S. Klasner

U.S. Geological Survey and Western mlinois University

T.M. Kehn

U.S. Geological Survey

\author{
Robert M. Thompson \\ U.S. Bureau of Mines \\ 1983
}

\section{STUDIES RELATED TO WILDERNESS}

Under the provisions of the Wilderness Act (Public Law 88-577, September 3, 1964) and related acts, the U.S. Geological Survey and the U.S. Bureau of Mines have been conducting mineral surveys of wilderness and primitive areas. Areas officially designated as "wilderness," "wild," or "canoe" when the act was passed were incorporated into the National Wilderness Preservation System, and some of them are presently being studied. The act provided that areas under consideration for wilderness designation should be studied for suitability for incorporation into the Wilderness System. The mineral surveys constitute one aspect of the suitability studies. The act directs that the results of such surveys are to be made available to the public and be submitted to the President and the Congress. This report discusses the results of a mineral survey of the Burden Falls Roadless Area (09-103) in the Shawnee National Forest, Pope County, Ill. The area was designated for further planning during the Second Roadless Area Review and Evaluation (RARE II) by the U.S. Forest Service, January 1979.

\section{MINERAL RESOURCE POTENTIAL SUMMARY STATEMENT}

The Burden Falls Roadless Area contains 3658 acres in the Shawnee National Forest, Pope County, Ill. Bedrock consists of gently dipping beds of sandstone of Pennsylvanian age, partly covered with loess of Pleistocene age. Several faults of unknown displacements cut the bedrock. Rock suitable for construction material is the only identified mineral resource. Numerous sources of similar rock outside the study area are more readily accessible. There is a low potential for fluorspar, coal, oil, and gas.

\section{INTRODUCTION}

The Burden Falls Roadless Area (fig. 1) covers 3658 acres in the Shawnee National Forest, Ill. It is located in T. $11 \mathrm{~S}$., R. 5 and 6 E., about $4 \mathrm{mi}$ northwest of Eddyville, IIl. Access to the area is good via a network of county roads, but only a few jeep trails penetrate the interior. Altitudes range from about 526 $\mathrm{ft}$ near Watkins Ford in the southwest corner of the study area to about $800 \mathrm{ft}$ in the northwest corner; local relief is much less than the maximum regional relief of $274 \mathrm{ft}$. The area is drained by Bay Creek, which flows southwest through the area, and by Burden Creek, which flows north from its source in the northwest part of the study area.

Vegetation consists predominantly of secondgrowth hardwoods; conifers have been introduced along the northern edge of the area. Small brushy tracts are managed as game lands. Undergrowth is dense on south-facing slopes.

\section{Previous Investigations}

Although no previous detailed geologic mapping has been done in the study area, several regional geologic and economic mineral studies encompass it. Engelmann (1866) studied the geology and economicmineral potential of southern Illino is, and Smith (1957) studied the strippable coal reserves of Pope County. Weller (1940) investigated the oil and gas potential of southern Illinois. According to the Illinois State Geological Survey's oil and gas development map of the New Burnside area, several oil and gas tests have been drilled around the perimeter of the study area and one well was drilled within the area(fig. 3 ).

\section{Present Studies}

Both the U.S. Geological Survey (USGS) and U.S. Bureau of Mines (USBM) conducted field studies in the Burden Falls Roadless Area during the spring of 1980. The studies consisted of geologic mapping and the collection of bedrock, stream-sediment, and soil samples. In addition, a special coal-reconnaissance 


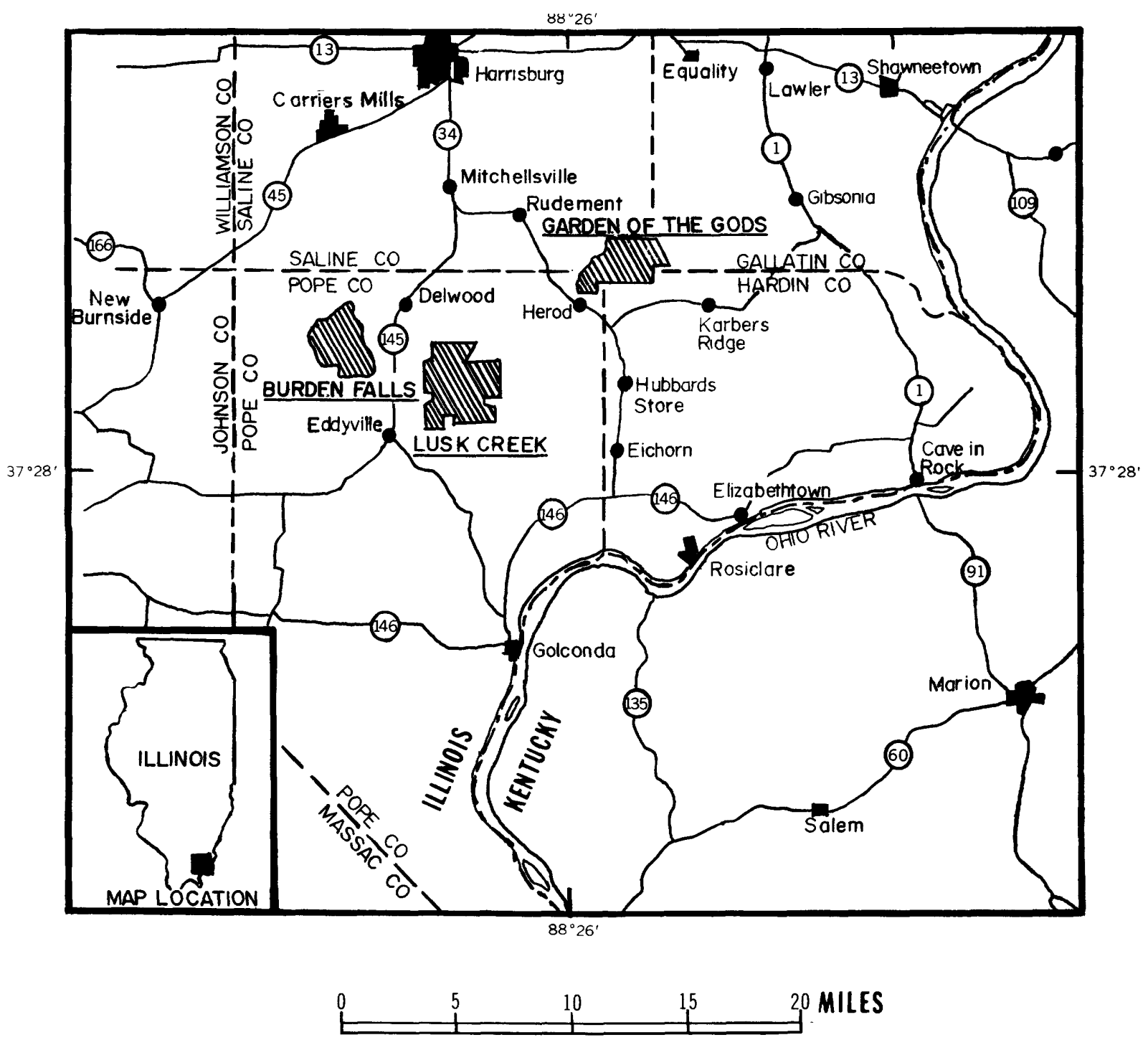

Figure 1.-Index map showing location of Burden Falls Roadless Area and other roadless areas in southeastern Illinois. 
survey was conducted to evaluate coal resources. The USGS collected 17 bedrock samples, 24 streamsediment samples, and 22 soil samples for microscopic or geochemical analyses (Klasner and Day, in press[a]). The USBM did semiquantitative-spectrographic analyses for 42 elements, and atomic- absorption and chemical analyses for selected elements on 12 bedrock specimens (table 1). Preliminary ceramic evaluation and lightweight-aggregate tests were performed by the USBM Tuscalossa Research Center, Tuscaloosa, Ala.

\section{Acknowledgments}

Members of the Illinois State Geological Survey helped considerably in this study. Jack A. Simon, Director, provided geologic data. James C. Bradbury and James W. Baxter, geologists who worked in the southern Illinois region, spent several hours discussing the geology of the region and provided well-log data and other unpublished data. U.S. Forest Service personnel, Vienna Ranger District and Harrisburg Supervisors office, provided trail maps and land-status data. Bradford Williams of the U.S. Bureau of Mines and Daniel Shuart and Don O'Brien of the U.S. Geological Survey assisted in field investigations. Katherine Portner of the U.S. Geological Survey provided technical assistance in the preparation of this report.

\section{SURFACE- AND MINERAL-RIGHTS OWNERSHIP}

Forest Service records indicate Federal ownership of about 82 percent of the surface rights and 62 percent of the mineral rights within the study area (fig. 2). Federal-land tracts are designated as having outstanding mineral rights where one or more mineral commodities are retained under private ownership as a condition of transfer. Federal lands were acquired by purchase or exchange, under the authority of the Weeks Act of 1911 by the U.S. Department of Agriculture, Forest Service.

An oil and gas lease application, filed in 1972 , includes about 36 percent of the roadless area (fig. 2). Portions of the area applied for under that document have oil and gas rights held by private interests.

\section{GEOLOGY}

The Burden Falls Roadless Area is located in the loess-covered unglaciated Shawnee Hills section of the Interior Low Plateaus Physiographic Province (Leighton and others, 1948). Structurally, it lies near the southern edge of the Illinois Basin within strata of Pennsylvanian age. The axis of the McCormick anticline (Treworgy, 1981) is located along its northwest margin, and the study area is situated about $6 \mathrm{mi}$ west of the Lusk Creek fault zone (Weller and others, 1952) which marks the western edge of the Illinois-Kentucky fluorspar district.

Bedrock consists primarily of gently dipping beds of Pennsylvanian sandstone as shown in figure 3. Major structures in the area are a northeast-trending syncline and northerly trending faults of unknown displacement which appear to offset the synclinal axis.

\section{MINERAL RESOURCE POTENTIAL}

The only identified mineral resource in the
Burden Falls Roadless Area is rock suitable for construction materials. Other commodities that may be present in the area but have a low potential include fluorspar and associated barite, galena and sphalerite, as well as coal, oil, and gas. Silver and gold were detected in the geochemical samples, as discussed below.

\section{Construction Materials}

Sandstone from this area could be utilized as construction fill for local projects, but numerous sources of this type of material are present throughout the Shawnee Hills. Analytical results for Pennsylvanian sandstone samples (table 1) indicate that they do not have potential as a source of highsilica sand.

Preliminary ceramic evaluation of samples of an exposed shale indicate potential use for structural clay products (table 1). This shale is overlain by thick beds of sandstone, however, and is too thin to be a significant resource.

\section{Fluorspar and Associated Minerals}

Because barite, galena, and sphalerite are commonly associated with deposits of fluorspar, they are considered jointly in the following discussion. Estimation of resource potential is based primarily on analyses of geochemical data given in Klasner and Day (in press [a] ). Analysis was done in three ways: 1) comparison of major indicator elements for fluorspar with average crustal values given in Turekian and Wedepohl (1961), 2) association of anomalous values of indicator elements with mapped faults, and 3) comparison of major fluorspar-indicator elements at Burden Falls Roadless Area with those from a part of the Lusk Creek Roadless Area in which the geology is similar and where the fluorspar resource potential is moderate.

The main reason for assigning a low fluorspar potential to the Burden Falls Roadless Area is that the average values of major indicator elements for fluorspar and associated minerals (beryllium, barium, fluorine, lead,and zinc) are, at best, equal to or lower than average crustal values for these elements as given in Turekian and Wedepohl (1961). Zinc was not detected at the limit of detection $(200 \mathrm{ppm})$ in any bedrock sample (table 2 ).

Although average values of indicator elements in the study area do not suggest significant fluorspar mineralization, figure 4 shows that indicator elements from a few samples occur in anomalous concentrations relative to other samples in the study area. Anomalous is defined as an indicator element having a value that is greater than two standard deviations above the mean value of the sample population for a given sample type (bedrock, soil, etc.). Soil sample BS1 has anomalous beryllium, for example. Unpanned stream-sediment sample BF7 has anomalous fluorine and BF9 has anomalous beryllium and lead. Bedrock sample BB-104 has anomalous fluorine and lead. All of these samples lie near the easternmost fault in the study area (fig. 3), suggesting that some, however minimal, fluorspar mineralization occurred along this fault.

One might argue that overlying Pennsylvanian rocks mask fluorspar mineralization that typically occurs in underlying Mississippian strata in the Illinois- 


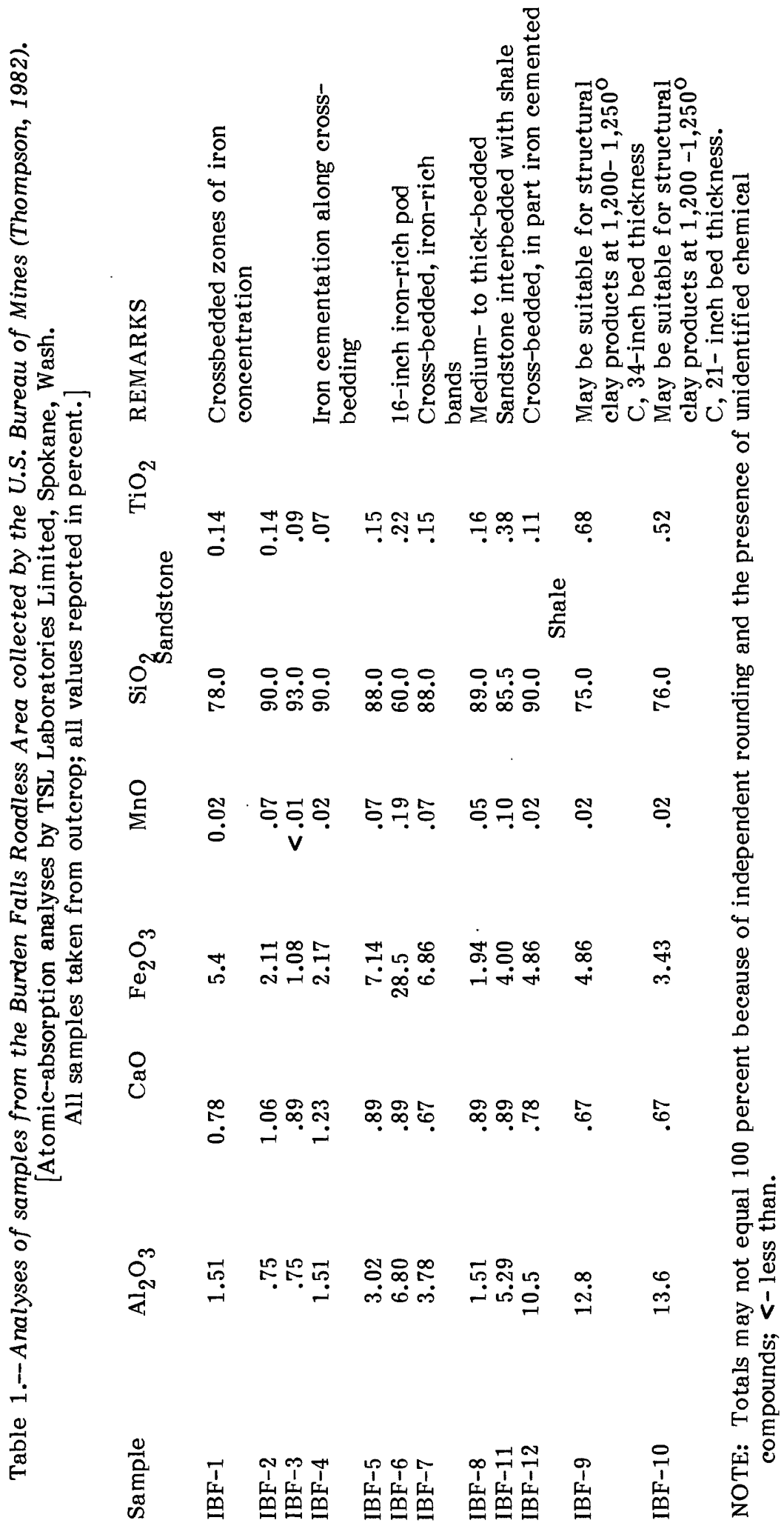




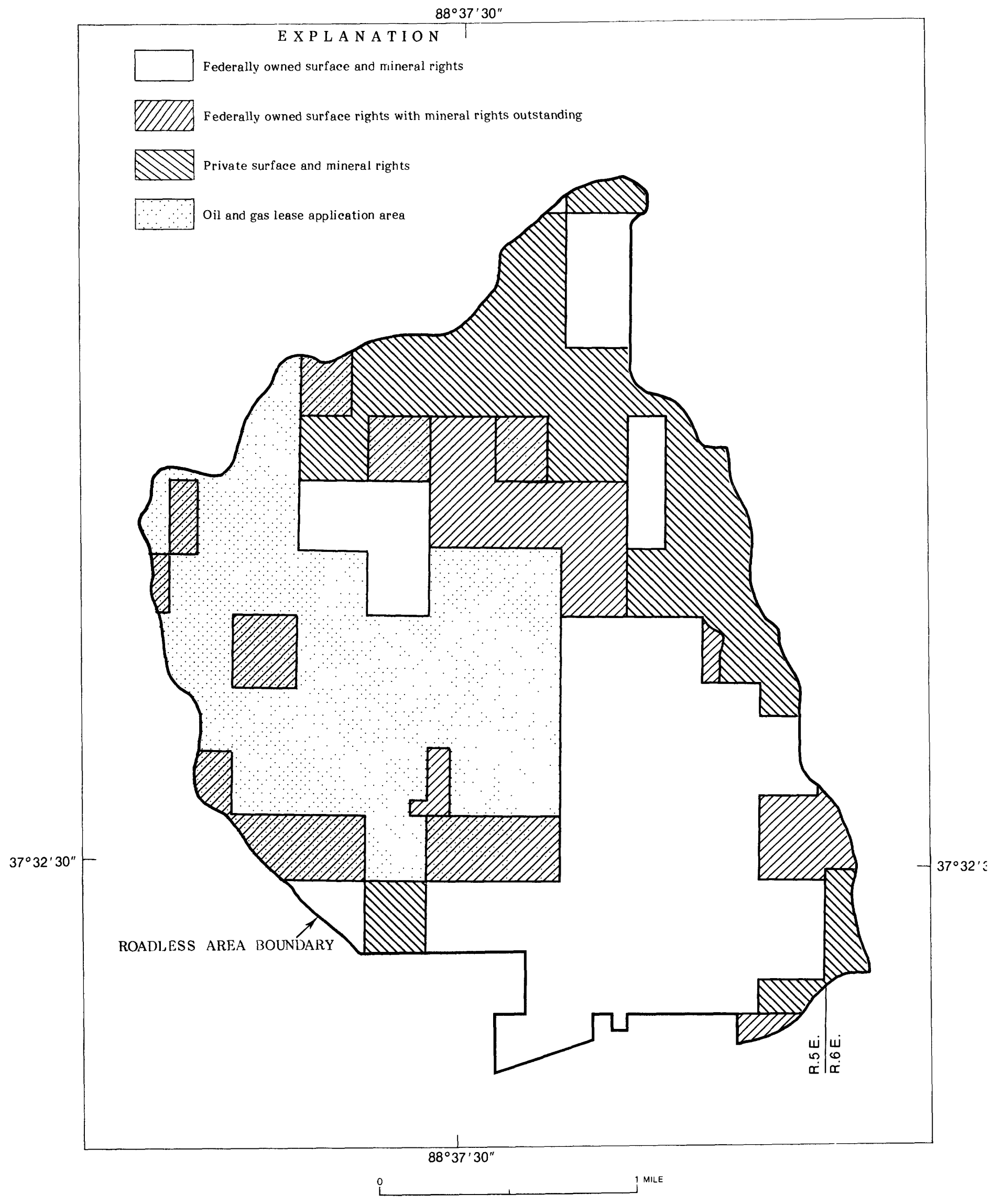

Figure 2.--Surface- and mineral-rights ownership within the Burden Falls Roadless Area. 


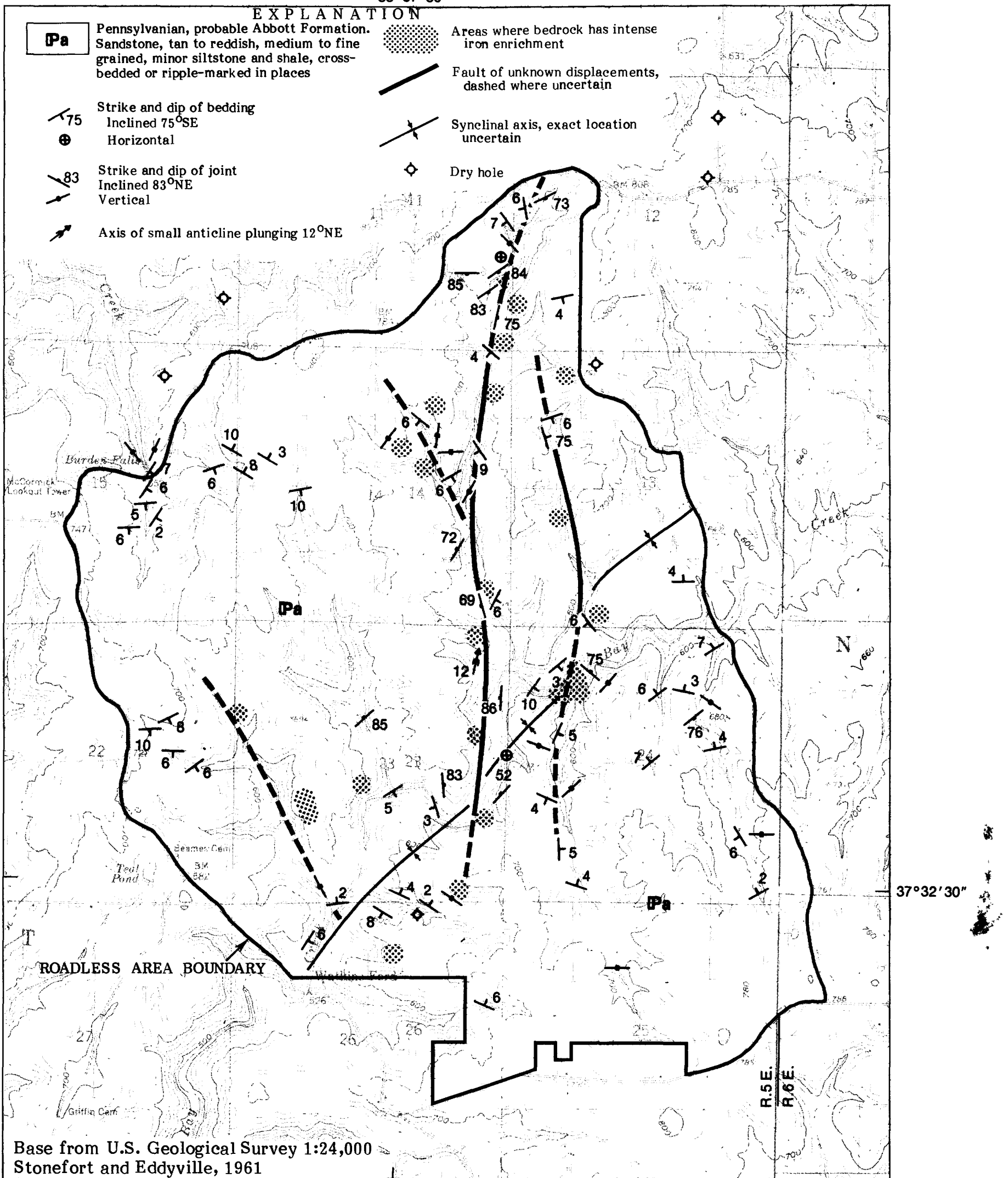

$88^{\circ} 37^{\prime} 30^{\prime \prime}$ Geology mapped by J.S. Klasner, 1980 1 MLLE

Figure 3.-- Geologic map of the Burden Falls Roadless Area. 
Table 2. --Comparison of elemental abundances in rocks from the Burden Falls Roadless Area with average crustal abundances of elements as given in Turekian and Wedepohl (1961). [All figures in parts per million (ppm)]

$$
\begin{gathered}
\text { SHALE } \\
1 \\
3 \text { samples }
\end{gathered}
$$

Element

$\mathrm{Ba}$

$\mathrm{Be}$

F

$\mathrm{Pb}$
$\mathrm{T}$

580

3

740

20
H/A

$300 / 217$

$3 / 2$

$300 / 300^{*}$

$50 / 25$
SANDSTONE

14 samples

$\mathrm{T}$

H/A

x0. $\quad 150 / 88$

$0 . x$

$1 / \mathrm{N}$

$270 \quad 100 / \mathrm{N}$

$7 \quad 50 / \mathrm{N}$

$\mathrm{T}=$ Crustal abundances from Turekian and Wedepohl.

$\mathrm{H}=$ Highest value measured in Burden Falls Roadless Area.

$\mathrm{A}=$ Average value measured in Burden Falls Roadless Area.

$\mathrm{x} 0 .=$ tens of $\mathrm{ppm}$.

$0 . x=$ tenths of ppm.

$\mathrm{N}=$ element not detected at limit of detection.

* Two samples had values of 300 and the other had a

value 100 , the exact value is not known. 


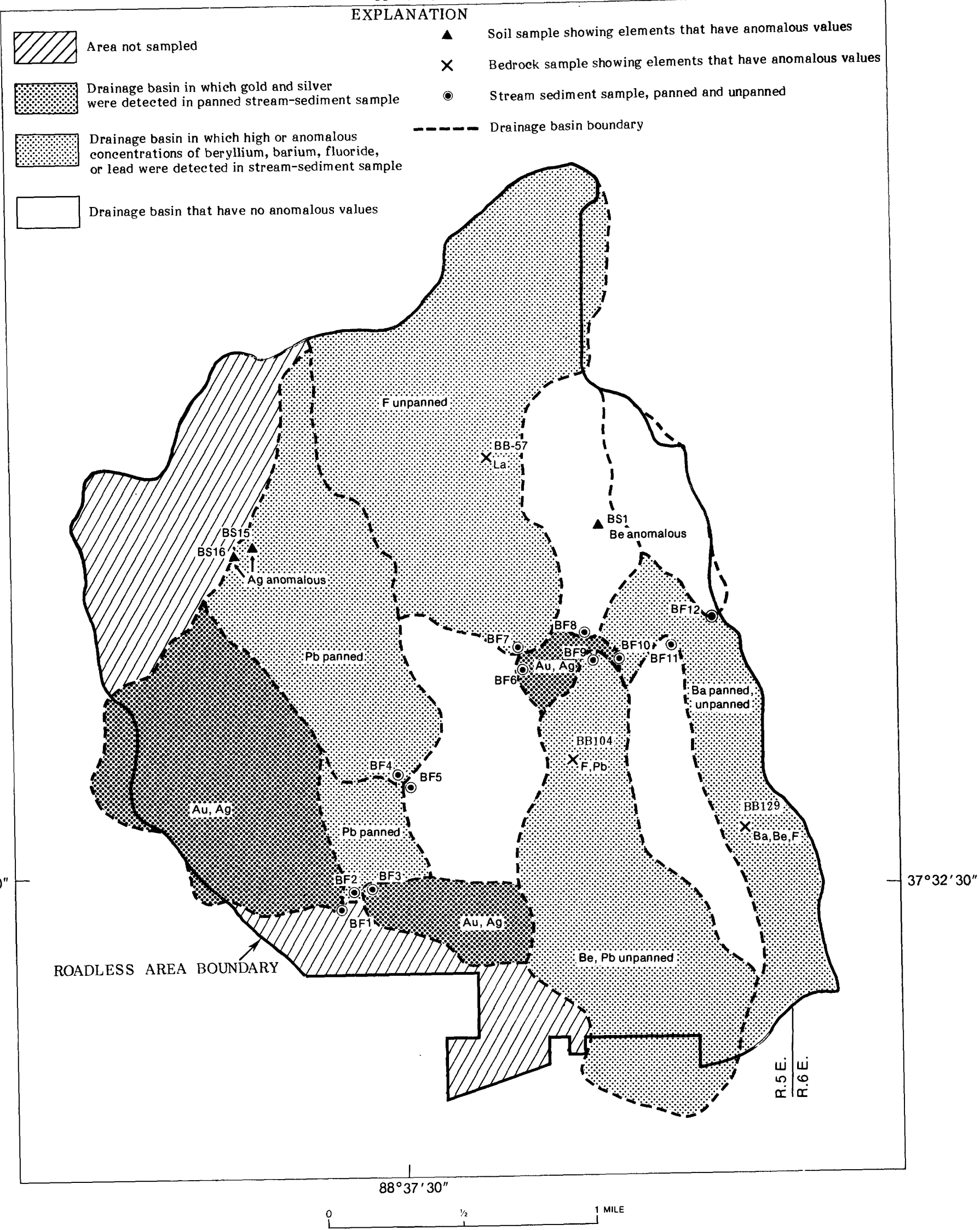

Figure 4.--Drainage basins sampled in the Burden Falls Roadless Area and localities of high or anomalous elemental concentrations in soil and stream-sediment samples (Klasner and Day, in press). Anomalous means that the elemental value is greater than two standard deviations above the mean. 
Kentucky fluorspar district (Grogan and Bradbury, 1968). But comparison of data from a part of the Lusk Creek Roadless Area (Klasner and Day, in press [b]) that is geologically similar to the Burden Falls Roadless Area indicates that this is not the case. In general, average and highest values of major indicator elements at the Lusk Creek study area are generally higher than those at the Burden Falls study area, suggesting that there is not significant fluorspar mineralization in the underlying Mississippian strata at the Burden Falls Roadless Area.

\section{Coal}

No outcrops of coal were found within the study area and available data indicate that only coal beds of less than approximately $14 \mathrm{in}$. in thickness may occur in the region. Table 3 describes reported occurrences of coal around the study area. Sample sites C-4 and C-5 (fig. 5) were visited during the coalreconnaissance investigation but the coal occurrences could not be found. Traces of coal were reported in a few of the well logs near the study area and all beds are estimated to be less than 14 in. in thickness. No coal-resource estimates were made for the study area.

\section{Oil and Gas}

Resource potential for oil and gas in the Burden Falls Roadless Area is estimated to be low. Dry oil and gas test holes have been drilled around the vicinity, as well as one within the study area (fig. 6). A 1,692-foot dry hole was drilled into Mississippian limestone in the SE $1 / 4$, sec. 10 , T. $11 \mathrm{~S}$., R. $5 \mathrm{E}$. It was drilled on an anticline that lies along the northwest margin of the study area. Weller $(1940, p$. 59) reports that there were shows of oil in some of the test holes drilled near the study area, but none were of commercial interest.

Strata older than Mississippian have oilproducing potential elsewhere in Illinois (Bell and others, 1964), but have not been tested by any of the wells near the Burden Falls study area. Weller (1940, p. 14), however, states that "prospects for oil and gas production in southern Illino is are not particularly favorable", and "the presence of fresh water in beds as old as Ordovician in several places and at considerable depth suggests that under-ground circulation may have been effective enough to flush out any oil that may have existed in some structurally favorable localities."

Even though oil and gas lease applications have been filed on 36 percent of the study area, the six oiltest holes within and adjacent to the area, as well as Weller's data on deeper geologic horizons, indicate that the potential for commercial accumulations of oil and gas within the Burden Falls Roadless Area is low.

\section{Silver and Gold}

Spectrographic analyses of soil samples BS15 and BS16 indicate the presence of silver and similiar analyses of panned stream-sediment samples BF1, BF 2, and BF6 indicate the presence of silver and gold (fig. 4). Reanalysis of additional material from these sample sites by spectrographic, fire-assay, and atomicabsorption methods verified the presence of gold but not silver and only in one sample; the recollected sample from panned stream-sediment site BF6 contains a trace of gold. The results of this analytical work do not suggest a resource potential for gold or silver, but further study of the distribution of these elements in southern mlinois may be warranted.

\section{REF ERENCES CITED}

Bell, A.H., Atherton, Elwood, Buschbach, T.C., and Swann, D.H., 1964, Deep oil possibilities of the Illinois basin: Illinois State Geological Survey Circular 368,38 p.

Bristol, H.M., 1967, Structure map on the base of the Beech Creek (Barlow) limestone in Illinois: Mlinois State Geologic Survey, scale 1 inch $=6$ miles.

Engelmann, Henry, 1866, Geology of Johnson, Pulaski, Massac, and Pope Counties, in Worthen, A.H., Geology: Geological Survey of Mlinois, v. 1, p 376-495.

Grogan, R.M., and Bradbury, J.C., 1968, Fluorite-zinclead deposits of the Illinois-Kentucky mining district, in Ridge, J.D. (ed.), Ore Deposits of the United States 1933-1967, (Graton-Sales Volume): American Institute of Mining, Metallurgical, and Petroleum Engineers, vol. 1, p. 370-399.

Mlino is State Geological Survey, 1981, Oil and gas development map, New Burnside area: Blueline copy of original map kept in State Survey files, obtained January 1981.

Klasner, J.S., 1983, Geologic map of the Burden Falls Roadless Area, Pope County, Illinois: U.S. Geological Survey Miscellaneous Field Studies Map MF 1565-A, in press.

Klasner, J.S., and Day, G.W., in press(a) Geochemical survey of the Burden Falls Roadless Area, Pope County, Ilinois: U.S. Geological Survey Miscellaneous Field Studies Map MF 1565-C.

Klasner, J.S., and Day, G.W., in press (b), Geochemical Survey of the Lusk Creek Roadless Area, Pope County, nlinois: U.S. Geological Survey Miscellaneous Field Studies Map MF 1405-C.

Leighton, M.M., Ekblaw, G.E., and Horberg, Leland, 1948, Physiographic divisions of Illinois: Illinois State Geological Survey Report of Investigation 129,19 p.

Smith, W.H., 1957, Strippable coal reserves of nlinois, Part I - Gallatin, Hardin, Johnson, Pope, Saline, and Williamson Counties: Illinois State Geological Survey Circular 228, 39 p.

Thompson, R.M., 1982, Mineral resource investigation, Burden Falls Rare II further planning area, Pope County, Illinois: U.S. Bureau of Mines Open File Report MLA 32-81, 13 p.

Treworgy, J.D., 1981, Structural features in Illinois a compendium: Illino is State Geological Survey Circular 519, 22 p.

Turekian, K.K., and Wedepohl, K.H., 1961, Distribution of the elements in some major units of the earth's crust: Geological Society of America Bulletin v. 72, p. 175-192.

Weller, J.M., 1940, Geology and oil possibilities of extreme southern Illino is - Union, Johnson, Pope, Hardin, Alexander, Pulaski, and Massic Counties: Illino is State Geological Survey Report of Investigation 71, $71 \mathrm{p}$.

Weller, J.M., Grogan, R.M., and Tippie, F.E., 1952, Geology of the fluorspar deposits of Illinois: Illinois State Geological Survey Bulletin 76, 147 p 
Table 3.-- Coal data, Burden Falls Roadless Area. [Locations of coal referred to on Figure 5.]

Coal data

Locations \#

$\mathrm{C}-1$

C-2

C-3

C-4

C-5

C-6
Coal bed

Formation not

given

Delwood(?)

Battery Rock

Reynoldsburg

Formation not given

Reynoldsburg
Thickness (in.)

18

$42(?)$

unknown

17

12

11
Remarks

Prospect, reported by others (Engelmann, 1866)

Abandoned mine, locally called Ice House coal

(Smith, 1957)

Abandoned mine (Smith, 1957)

Outcrop (Smith, 1957)

Slaty, impure coal outcrop

(Engelmann, 1866)

Abandoned mine (Smith, 1957) 


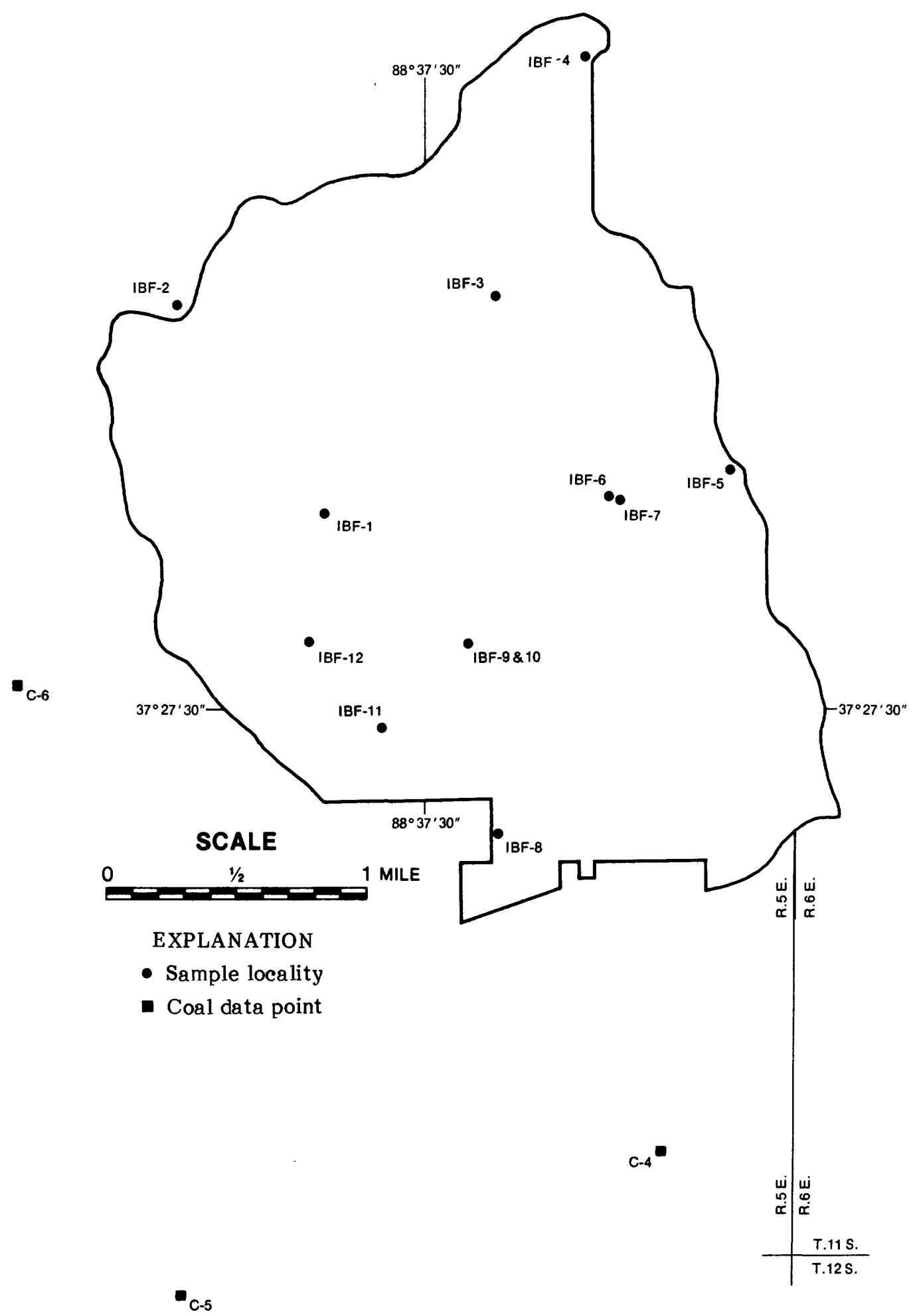

Figure 5.-Bureau of Mines sample localities and coal sites. 


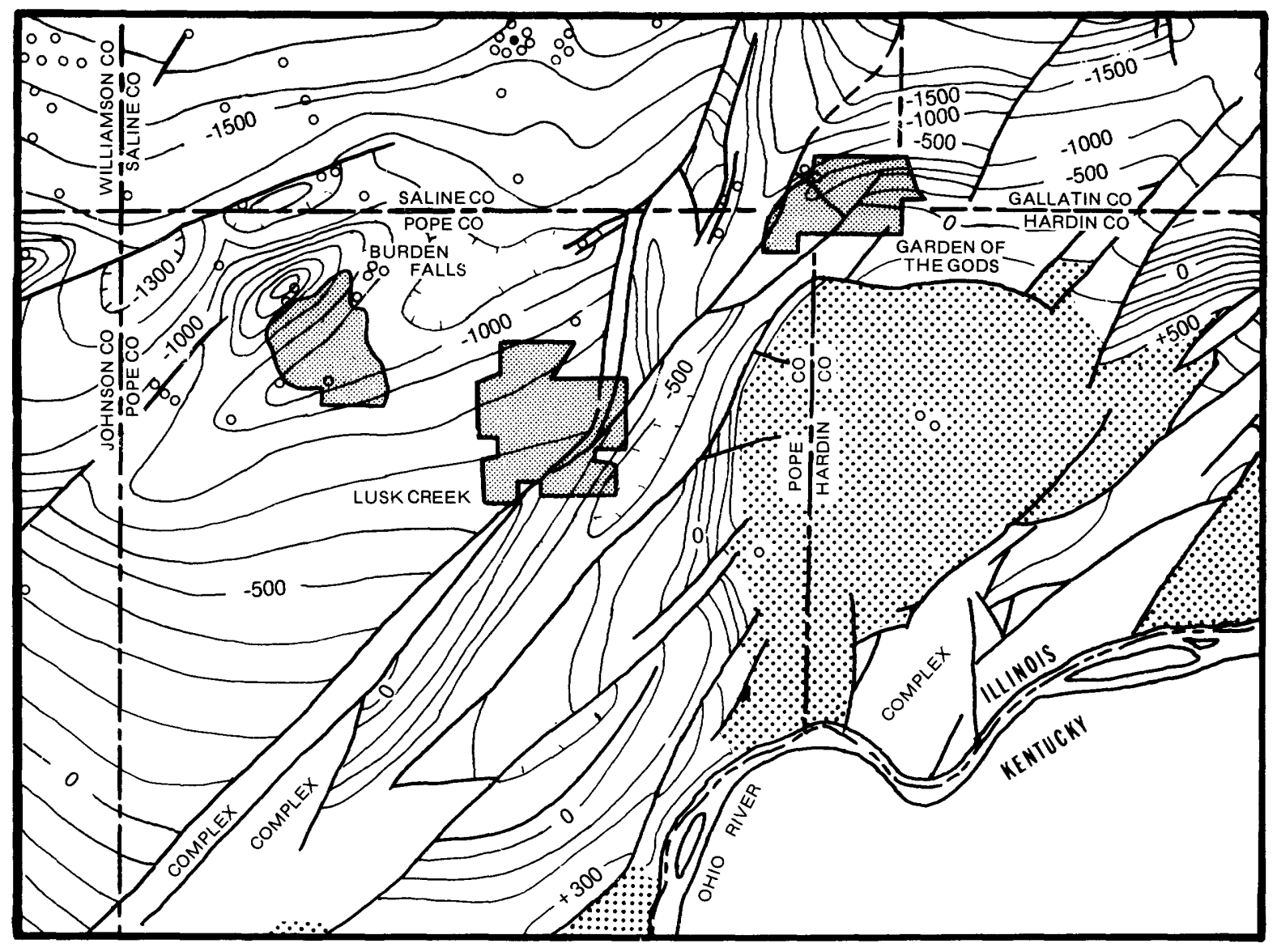

EXPLANATION

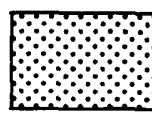

Limit of Beech Creek Limestone

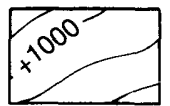

Structure contour, $100 \mathrm{ft}$. interval
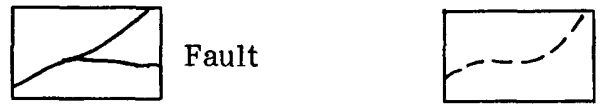

Inferred fault

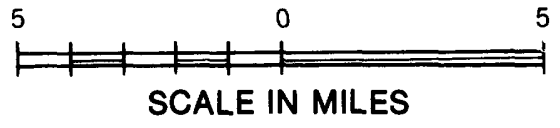

- Oil well

- Dry hole

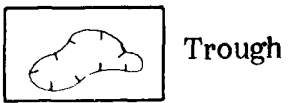

Figure 6.-Structure contour map of the Beech Creek Limestone and location of oil and gas wells relative to the Burden Falls Roadless Area. The structure contour map is from Bristol, 1967. 